\title{
Commentary: Can coronary artery fistulae be an indication for transarterial aortic valve replacement over surgical aortic valve replacement?
}

\author{
Vincent R. Conti, MD
}

\footnotetext{
From the Division of Cardiovascular and Thoracic Surgery, Department of Surgery, University of Texas Medical Branch, Galveston, Tex.

Disclosures: Author has nothing to disclose with regard to commercial support.

Received for publication April 16, 2019; accepted for publication April 16, 2019; available ahead of print May 21, 2019.

Address for reprints: Vincent R. Conti, MD, Division of Cardiovascular and Thoracic Surgery, Department of Surgery, University of Texas Medical Branch, 301 University Blvd, Galveston, TX 77555 (E-mail: vconti@utmb. edu).

J Thorac Cardiovasc Surg 2020;159:e31

$0022-5223 / \$ 36.00$

Copyright (C) 2019 by The American Association for Thoracic Surgery

https://doi.org/10.1016/j.jtcvs.2019.04.055
}

The experience with a rare single case such as that reported by Folino and colleagues, ${ }^{1}$ where an attempt at open surgical aortic valve replacement failed because of severe coronary artery fistulae with inability to achieve sustained cardioplegic arrest and good visualization of the aortic valve region, might not ordinarily be considered adequate grounds for future decision making. However, their success with transarterial aortic valve replacement (TAVR) and their description of the difficult and dangerous conditions during their attempt at surgical aortic valve replacement should easily justify resorting to TAVR should a similar case present itself to other surgeons. Under usual circumstances, surgical decision making regarding procedure choice is made on the basis of more than 1 case experience, but as the authors point out this is an extremely rare condition. After describing this case to our own cardiac surgeons, not 1 of 4 surgeons had ever seen or heard of a similar case. This makes the experience of reviewing this case report all the more valid a rationale for the decision to resort directly to TAVR should a comparable case present. Their detailed documentation of the anatomy and severity of the coronary fistulae by preoperative catheterization is also an important consideration in future decision making.

The authors also address the other option for myocardial management and provide justification for choosing TAVR patients. $^{2}$

\section{References}

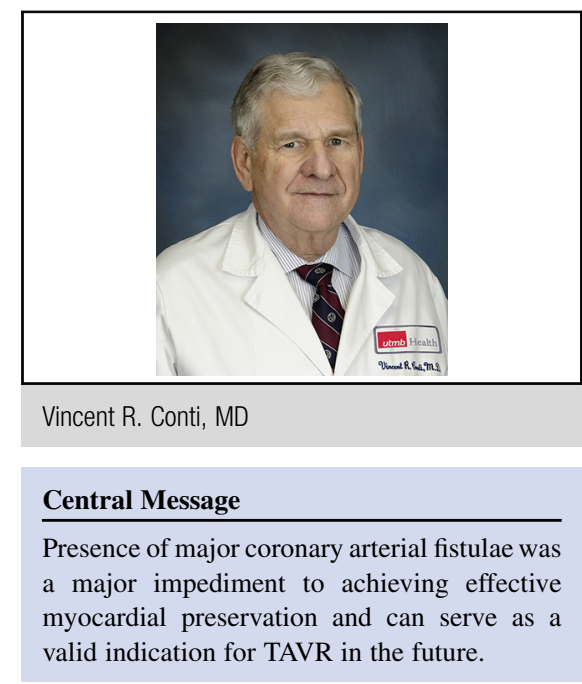

See Article page e27.

instead. It is true that the authors interrupted some of the coronary fistulae, particularly those connected to the pulmonary trunk, but if those were believed to be symptomatic after TAVR, they likely could be occluded by coil embolism. TAVR as the best option is all the more easily justified by the results of the Partner 3 Trial, which documented improved outcomes with TAVR versus SAVR in low-risk

1. Folino G, Bernardinello V, Carrozzini M, Bejko J, Gerosa G, Bottio T. Transfemoral aortic valve replacement as a solution in aortic valve stenosis and coronary artery fistulas. J Thorac Cardiovasc Surg. 2020;159:e27-9.

2. Mack MJ, Leon MB, Thourani VH, Makkar R, Kodali SK, Russo M, et al. Transcatheter aortic-valve replacement with a balloon-expandable valve in low-risk patients. N Engl J Med. 2019;380:1695-705. 